\title{
Unique Value of Human Resource Management in Organization
}

\author{
Dr. Elida Ciriković
}

elida.cirikovic@unhz.eu

\author{
Doi:10.5901/ajis.2015.v4n2s1p69
}

\begin{abstract}
Modern economic events are occurring in a complex and turbulent environment. We are witnessing a process of globalization and internationalization of economic activities, which carry a myriad of new opportunities and chances and can be considered as threats to existence and prosperity of business. Will the new opportunities bechances or threats; it will primarily depend on the human resources of the company and its management. It is the main factor of growth, development and is decisive and crucial factor in the realization of the business goals and strategies. The main determinant from which everything starts, from which everything ends and everything depends is precisely the human factor, and not any other element of the business system. The fact is that traditional management with high organizational structures is slowly but surely transcending and giving away to a shallow, low organizational structure so called "Downsizing", which is the embodiment and symbol of modern trends in the management functioning. Such a structure entails a different communication way of management and Human Resources of a company. The aim of this paper is to once again evidence that the management of human resources is an essential part of survival and further development of modern business systems. The aim of this work will vary by presenting basic determinants of human resources from the management perspective, which will be confirmed by the fact that human capital is the most important capital of the business system. Precisely from its creativity, innovation, flexibility, the overall competitive position of the company will depend on. Human resources have the power of learning. Thanks to the knowledge and power of learning, human resources are the basis of introducing changes.
\end{abstract}

Keywords: management, human resources, competition, environment, organization, strategy.

\section{Introduction}

Human resources are unique to each organization and as such they can not be copied and as a system be transferred to another organization. It is in a word, intellectual capital and is in the interest of any organization to constantly improve it with knowledge, skills and additional training, which will lead to developing creativity, so essential in sharp and more turbulent environment. In this way it will create an increased productivity and also increase of the market value. We are the witnesses and participants of transition and globalization, which brings new understandings and adaption. The survival and adaption in such complex conditions, is possible only with a modern and innovative approach to the human resource management, in circumstances where the employees are considered as associates and partners to the management. The main goal of the human resources management is to align the goals and interests of individuals with goals and interests of the organization. The success of organisation will depend on the degree of succeeding this.

Human Resource Management is basically created as a response to competition which is dictated by Japanese companies (with its philosophy of teamwork) so it became a big threat to traditional business philosophy. The process of human resource management includes two sides. On one side are those who manage, while on the other one are those who are governed.

The relations of dominance and subordination chareshed for thousands of years, cedes its place to the relations of cooperation and creative solution of set goals, raising personality, integrity and initiative of the employee to a higher level.

What characterizes the MHR is that:

- Was created as a profession closely related to the practice-which gives it the character of practicality.

- It is originated and developed based on findings and the impact of other disciplines: organizational behavior, industrial psychology -multidisciplinarity.

- What is the outcome in practice, it puts the emphasis on individual activities and other scientific disciplines that helped him also in - there is no single conceptual framework.

Human resource management as a scientific discipline deals with the study of all aspects of employment in the organization. Before, this scientific discipline was called a Personal Management. (Petković M., Janićijević N., Milikć Bogičević B., 2008.). 
Under human resources are considered whole human resources in the organization: the available knowledge and experience, useful capacities and skills, possible ideas and creations, level of motivation and interest in achieving organizational objectives and etc. (Kulić, Ž., 2005, pg. 21).

If the management of the organization is observed as a system, then the management of human resources, its subsystem that for each position provides a capable and responsible staff and allows that every individual and organization as a whole achieve maximum business goals.

\section{Basic Guidelines}

In the modern business management of human resources there are four basic meanings:

- The scientific discipline

- Managerial function

- Special business function in the organization

- Specific management philosophy (Bahtijarević-Šiber, F. 1999.)

The concept of human resources can be seen as a main mean for achieving the success, quality, profitability, efficiency, effectiveness, cost-effectiveness in achieving set objectives.

The main objective of the human resource management is the maximal possible return on investment in order to ensure the quality of human capital on one hand and minimize financial risks and costs on the other hand. When talking about human resource management goals, it should be noted that it can be viewed from the standpoint of the workplace and from the standpoint of the entire organization. If one takes into account the specific work place, then it is primarily related to individual performances, the desired level of productivity, employees' satisfaction. If one takes into account the organizational level, then the human resource management goals refer to the increase of an average productivity, improving the quality of working conditions and as the most important one is existence in the market through creation of competitive advantage and adaptability to changes.

Kulić divides the objectives and tasks of human resource management on economic and social (Kulić, Ž,, 2005).

The most important economic objectives are: increase the motivation to work and productivity; reduce operating costs and rational use of available resources; ensuring competitive advantage of the organization; adapting to change and ensuring profits.

The most important social objectives are: providing good conditions for work; improving the financial and social status; improving individual potentials of employees; building good human relations and health care for employees.

\section{Factors of Human Resource Management}

As already stated, human potential is the most important factor of market success, therefore it is necessary to constantly develop it and improve it. Of great importance for efficiency and effectiveness are the factors that an organization should have in mind in order to bring them under control. According to a group of authors, all factors are divided into internal and external (Petković M., et al. 2008.).

Internal factors come from:

- Organization itself: organizational structure, organizational culture, strategy, technology.

- Employees: personal characteristics, motivation, interests, attitudes and abilities.

- Jobs: the nature of job, job requirements, satisfaction

External factors come from the environment outside the organisation and they can not be influenced by the organisation. They are formed under the influence of state regulations, legislation, and tendency in the labor market, competition characteristics, consumers' demands and desires.

Another group of authors divides all Human Resource Management factors into economic, factors arising from personnel and scientific-technological development and other factors (Damjanović,P., Suša B., Škunca D., Milenković S., Ristić Ž., 2012.).

The group of economic factors consists of:

- The processes of globalization, market openings - to survive in a competitive environment, organizations must rely on their employees

- Changing the method of doing business. - New economic conditions, competition imposes a need for organization adapt and find modalities for the rational use of human resources 
- Diversification of markets labour force -contemporary trends of globalization have caused the interference of workers from different countries, the development of new technology, forms of work and labour relations.

- As it comes to narowerr specialization, work has become more competitive, which entails the need for continuous improvement, while constantly adjusting the process of human resource management

- The occurrence of crisis -then human resources are gaining the importance, because it is characterized by creativity, for which, along with their mobility, those who govern them are accountable.

- Japanese economic growth - the essence of the Japanese economic miracle is not in their superior technology or cheap raw materials, but in a more humane and closer relationship of management towards its employees, who perceive the organization as their home.

The most important factors of human resources and scientific-technological developments that affect the development of human resources management are:

- The occurrence of new occupations and professions - their occurrence is conditioned by the development of science and technology, which also condition the changes in human resource management

- Scientific and technological development - To manage the highly developed technology a well-trained staff is needed, while MHR must follow these changes

- Increase of employees' educational level - occurs as a result of scientific and technological revolution. Competitiveness can not be sustained without relying on knowledge, innovations, which causes the development of MHR.

Among other factors, the management of human resources are distinguished based on:

- Change of the values and life style - modern society is a consumer society and unsatisfied needs lead to dissatisfaction and frustration of people, which results in a lack of motivation for their work. MHR has to invest in people and in their development.

- Demographic changes - due to economic under development and poverty, it leads to migration from these countries to developed countries, which changes the structure of employees in organizations, different cultures, religions, attitudes. The role of human resource manager is to adapt such diversity to the organization needs.

- Increased work of women engagement - in the structure of employees the share of employed women is increasing from year to year. Some works are better performed by women compared to men, which human resources managers should certainly have in mind.

\section{Contemporary Trends in the Formation of Human Resources}

Business in modern conditions, conditions the organizations to think differently, and also to adapt its organizational structures. Bureaucratic, hierarchical structure became part of the past, while new and low policies have a significant impact on the management of human resources. The driving force of all changes in modern enterprises derives from the fact that the main expansion factor is the knowledge. Modern organizations see as the main factor of development and competitive advantage in people and in managing their resources. The main development resource is knowledge. What is the significance of knowledge and its continuous improvement is seen from the constatation, that the total knowledge doubles every 5 to 8 years. Contemporary trends and technology development has caused lifelong learning because learning is no longer ends with graduation. Today, the basic element by which a successful company differs from the other, are just the people with their knowledge and methods of work. The crucial importance for business development is reflected in human resources, which is the only resource, which increases through spending. The significance of this resource is even greater if one takes into account that the other business resources (especially natural) are less. Development and changes in scientific and technological fields have caused significant changes in the organization and functioning of contemporary economic entities. Inevitably field of changes is also the field of human resources management Trends that have caused changes in the MHR:

- The increase of competition is certainly the most important factor that affects the MHR, in order for organisation to cope with it decreases the prices, which entails reduction of employees, but also the emergence of growing demands for more intensive work. Another way to answer the increasing competition may be an increase product quality, which affects the human resources by introducing in the first line $t$ requirement for highly specialized and skilled labor force.

- Globalization and internationalization of business leads to an increased number of multinational companies. Such a size entails employment of significant number of experts in human resources; therefore it is necessary 
to develop a global standardization while restoring a balance between local and global managers.

- Development of the Internet and information technology directly affects the MHR, causing changes in the ways of doing business in the sector of human resources. The use of technology leads to changes in the organization itself and also to the changes in the management of human resources.

- Legal framework, which obliges the human resources managers to act in accordance with the applicable legal provisions, which regulates the labour rights, primarily the areas of employment, health and social care, unjustified dismissals, treatment of ethnic minorities.

- On one hand the respect of these provisions provides greater security to employees, but on the other hand it can be a result of lower employment rate (due to high costs).

- The ethic is especially important for human resources management, because as a notion it is connected with people. The issues of ethics are constantly present in the organization, because there is always a dilemma between what workers believe is right and what is in the interest of the organization.

- Best practice versus best suitability (Suša B., 2009.). Here is a question primarily on whether there is a best way of carrying out activities related to human resources, which would be applicable everywhere. A group of authors considers that there is a practice of human resources, the application of which can enable organizations to gain an advantage over its competitors and here we talk about the best practices. Based on the facts, in view of best practices, human resources can influence increase of competitive advantage, but they must take into account the circumstances that are present in each organization. Here we talk, in fact, about the conditions that apply in an organization does not have to be in effect for another.

- Changes in the characteristics of the labour force (Petković M., et al.,2008.) are emphasized in two dimensions: primary (age, sex, race, ethnicity) and secondary: education, parental status, marital status, religious beliefs.

\section{The Concept of Human Resource Management}

The main task of MHR is to direct the potential of an individual, workers towards organizational results, using in this way his knowledge, skills and abilities to achieve the defined objectives of the organization. Therefore, one can say that the mission of MHR is to shape human behavior according to the needs and organisation objectives.

Šehic believes that the function of human resources management is increased productivity of employees, thus increasing in the most direct way the efficiency of enterprises (Šehić Dž., 2002.). In this paragraph one shall draw the conclusion that the basic specificity of the human resource management is reflected in the fact that it with its work, in the most direct way, affects the efficiency of other functions within the company. Therefore, successful management of human resources leads to multiple positive effects, but also the weaknesses in the work of this function are expressed multiply negatively on the business of the company as a whole. Only human behavior is seen as a complex system that depends on many interrelated sizes, starting from the individual with his knowledge, skills, motivation, and given circumstances. The thing that successful companies differ from less successful ones is the fact that in successful companies the emphasis is placed on the fact that all workers share the company's fate and through various ways of motivation, rewarding above all, encourage creative abilities of employees, but additional employee training system should not be ignored. Human resource management is gaining more importance in modern business as the fact is that the goals of the organization are realized by the most important capital - human resources.

What characterizes contemporary MHR is primarily the higher flexibility of the workplace, work organization and rewarding system. The crucial obligation of human resources manager is reflected in the responsibility on the reception of employees, bearing in mind the need to link the characteristics of the organization and characteristics of employees.

In order to establish connections between individual advancement and dynamic changes and development of organization, it is approached by developing individual skills through the training process, in accordance with the needs of the organization itself.

The tendency is to move payment to wards the relativity, due to individual contribution of company's achieved goals. Due to the turbulent environment, adding also the growing level of information technology application, there is a need and a necessity for human resources manager to have an active approach to human resources, as the organisation enabling better advancement and personal affirmation will be more attractive to them. On the other hand, the organization requires from employees a high level of professionalism, willingness and ability to work in teams, initiative and creativity. 


\section{Conclusion}

The need of organization to be competitive and in the long term optimally positioned in the market imposes the importance of human resource manager. This is even more present as the information exchange is faster and more complex. All above specified demands creative and innovative, responsible and motivated individuals, whose personal success is also the successes of the organization in which they work. Starting from the basic evolutionary laws that the strong and powerful ones do not survive, but only those who succeed to adapt to environment, the responsibility falls under human resources manager to engage and motivate each individual in the decision-making process, and thus they also bear some responsibilities for realized results. The fact is that contemporary organizations are increasingly turning to the human resources, as the only sourced capital. The importance that human resources have for the entire operation of business entity imposes the conclusion on the management of this most important resource of the company; it represents a strategic component of its general capability. One thing is certain. Human resources managers have to face many challenges that are imposed by the unpredictable and complex environment.

\section{References}

Bahtijarević-Šiber, F. Menadžment ljudskih potencijala, Zagreb, Golden Marketing,1999.

Damjanović,P., Suša B., Škunca D., Milenković S., Ristić Ž., Upravljanje ljudskim resursima, EtnoStil d.o.o. - Beograd,2012.

Kulić, Ž, Upravljanje ljudskim potencijalima, NIP Radnička Štampa,Beograd, 2005.

Petković M., Janićijević N., Milikić Bogičević B. Organizacija, Centar za Izdavačku delatnost Ekonomskog Fakulteta,Beograd,2008.

Šehić Dž., Strateški menadžment,Sarajevo 2002.

Suša B., Menadžment ljudskih resursa, Cekom-books d.0.o., Novi Sad, 2009. 